\title{
Hidden Blood Loss, Infection and Cost-Effectiveness of Tranexamic Acid Protocol in Primary Total Knee Arthroplasty
}

Primer Total Diz Artroplastisi İçin Traneksamik Asid Kullanımında Gizli

Kan Kaybı, Enfeksiyon ve Fiyat-Fayda Oranı Hakkı Çağdaş Basat', Berk Güçlü², Ömer Bozduman³, Yasin Köker, Cihan Kırçו15, Hicabi Sezgin'

${ }^{1}$ Ahi Evran University Faculty of Medicine, Department of Orthopaedic Surgery, KIRSEHIR,TURKEY

${ }^{2}$ Ufuk University Faculty of Medicine, Department of Orthopaedic Surgery, ANKARA, TURKEY

${ }^{3}$ Afyonkarahisar State Hospital, Department of Orthopaedic Surgery, AFYONKARAHISAR, TURKEY

${ }^{4}$ Ufuk University Faculty of Medicine, Department of Orthopaedic Surgery, ANKARA, TURKEY

${ }^{5}$ Memorial Ankara Hospital, Department of Orthopaedic Surgery, ANKARA, TURKEY

Yazışma Adresi / Correspondence:

\section{H. Çağdaş Basat}

Ahi Evran University Faculty of Medicine, Department of Orthopaedic Surgery, KIRSEHIR,TURKEY

T: +90 $5057721489 \quad$ E-mail: cagdasbasat@gmail.com

Geliş Tarihi / Received : 04.05.2018 Kabul Tarihi / Accepted : 30.05.2018

\footnotetext{
Abstract

Objective: The purpose was to evaluate the effect of combined administration of TXA on total blood loss, hidden blood loss, drain output, cost effectiveness and periprosthetic infection rate in patients undergoing unilateral primary knee arthroplasty. Sakarya Med J, 2018, 8(2):423-431 )

Materials and We enrolled fifty-eight patients with primary gonarthrosis undergoing unilateral primary knee arthroplasty between May 2014 and Methods December 2014. We compared 29 cases performed without the application of TXA to 29 cases performed with the application of TXA. Our TXA protocol consisted of three stages.

Results Postoperative hemoglobin and hematocrit levels were found to be significantly lower in the non-TXA group. Estimated blood loss, hidden blood loss, and drain output were found to be higher in the non-TXA group. Transfusion rate was lower in TXA group. The blood bank costs were found to be higher in the non-TXA group. The total direct cost was also higher in the non-TXA group. This was average $29.9 \$$ savings per case in the TXA group. No complication such as infection or thromboemboli was detected among the study groups.

Conclusion Combined topical and continuous up to 24 hours intravenous administration of TXA reduced the total blood loss and decreased drainage volume, as well as reducing hidden blood loss.

Level of evidence III.

Keywords blood loss, postoperative; hidden blood loss; tranexamic acid; total knee replacement
}

Öz

Amaç Tek taraflı primer total diz artroplastisi uygulanan hastalarda kombine traneksamik asid (TXA) kullanımının total kan kaybı, gizli kan kaybı, drenaj miktarı, kost efektivite ve periprostetik enfeksiyon oranı üzerine etkisini değerlendirmektir.

( Sakarya Tip Dergisi, 2018, 8(2):423-431).

Gereç ve 2014 yılı Mayıs ve Aralık ayları arasında primer gonartroz tanısı ile tek taraflı primer total diz artroplastisi uygulanmış olan 58 hasta çalışmaya

Yöntem dahil edilmiştir. TXA uygulanmamış 29 hasta ile TXA uygulanmış olan 29 hasta karşılaştırılmıştır. Söz konusu TXA protokolü 3 aşamadan oluş̧maktadır.

Bulgular Ameliyat sonrası hemoglobin ve hematokrit seviyeleri non-TXA grubunda anlamlı olarak düşük bulundu. Gene tahmini kan kaybı, gizli kan kaybı ve drenden olan kayıp miktarı non-TXA grubunda daha yüksek bulundu. Transfüzyon oranı TXA grubunda daha düşüktü. Kan bankası masrafları non-TXA grubunda daha yüksek bulundu. Total masraflar da gene non-TXA grubunda daha yüksek idi. TXA grubunda vaka bașına 29,9 USD daha az masraf söz konusu idi. Çalıșma gruplarında enfeksiyon veya tromboemboli gibi komplikasyonlara rastlanmadı.

Sonuç Topikal ve 24 saat sürekli intravenöz TXA'in kombine kullanımı total kan kaybı, drenaj hacminin yanı sıra gizli kan kaybı miktarını da azalıı. Kanit düzeyi III

Anahtar kan kaybı, ameliyat sonrası; gizli kan kaybı; traneksamik asid; total diz replasmanı 
Sakarya Med J.

2018;8(2):423-431

\section{Introduction}

Primary total knee arthroplasty (TKA) is associated with perioperative blood loss ranging from 800-1700 ml. 1-4 Allogenic blood transfusion mostly utilizes for perioperative anemia after primary TKA, although it includes disease transmission, risk of $A B O$ incompatibility, immunologic and allergic reactions and additional cost. Numerous blood conservation methods are used to reduce the risks of allogenic transfusion, including controlled hypotension, regional anesthesia, autologous blood transfusion, intraoperative blood salvage, and the use of erythropoietin and antifibrinolytic agents. But there is no certain consensus about the preferred technique .1,5-7 $^{-1}$

Antifibrinolytic agents block the lysine-binding sites on plasminogen, so plasminogen activation to plasmin is prevented. ${ }^{8,9}$ Tranexamic acid (TXA) and epsilon aminocaproic acid or aprotinin are mostly used antifibrinolytic agents. Among these drugs, TXA have been used more frequently for blood conservation method because it is cheaper, safer and more potent. Other antifibrinolytic drugs and fibrin spray have been also used to reduce blood loss, however aprotinin is associated with increased mortality and may lead to allergic reactions and precious aminocaproic acid has been associated with hypotension, cardiac arrhythmias, myopathy, and rhabdomyolysis, and less effective than TXA. Moreover, TXA is more potent and cheaper than fibrin sealants. ${ }^{5,6,9}$

In the literature, there are a lot of systemic reviews and meta-analysis about efficacy of TXA in primary TKA. In these studies, TXA was used in intravenous (IV), topical and combined administration forms. Numerous dosages and administration ways of TXA have been described in these studies. ${ }^{6,10-13}$ The main attention of the previous studies was to reduce total blood loss, which was usually measured by volume of drainage fluid, however hb concentration in drain and simultaneous venous sample is not the same. Hb concentration in the drainage can be less than in simultaneous samples of venous blood. ${ }^{1,14,15}$ Also, blood accumulates in the joint and around thigh after TKA, called as hidden blood loss, and it is considered that the hb concentration of hidden blood loss is higher than in the drains..$^{14,15}$ Indeed, these used TXA methods have reduced blood loss by decreasing the total drainage output and did not effectively affect the hidden blood loss with respect to drain output. ${ }^{1,3,16}$ Patients used TXA administrations have had lower post-operative hemoglobin than expected. ${ }^{13}$ Additionally, in previous studies demonstrated that hidden blood loss also can cause increasing hematom formation around the knee joint and these conditions can lead to have a higher incidence of periprosthetic infection. ${ }^{17-20}$ So we consider that the TXA method for using for reduction of total blood loss must reduce not only drainage fluid but also hidden blood loss. In our study, we combined both topical and continuous up to 24 hours IV administration of TXA. The aim of our study was to show the combined administration of TXA provided to reduce significant blood loss, but also reduce significant hidden blood loss.

\section{Materials and Methods}

All of the patients who undergone unilateral primary knee arthroplasty between May 2014 and December 2014 at Ufuk University Faculty of Medicine, Department of Orthopaedic Surgery included in our study were admitted with a diagnosis of primary gonarthrosis. The exclusion criteria were; usage of anticoagulant medication within pre-operative seven days, acute sepsis history, a coagulation defect or abnormal coagulation profile, cerebrovascular accident, myocardial infarction, atrial fibrillation, history of deep vein thrombosis (DVT) or pulmonary embolus (PE), preoperative international normalized ratio (INR) $>1.4$, activated partial thromboplastin time (aPTT) > 
$1.4 \times$ normal, platelets (PLT) $<140.000 / \mathrm{mm} 3$, renal or liver disease and those with allergy to TXA. Fifty-eight patients meeting the aforementioned criteria were included in our retrospective study. We compared 29 cases performed without the application of TXA to 29 cases performed with the application of TXA (250 mg Tranexamic acid, 5\% Ampule, $5 \mathrm{ml}$, Actavis Drugs Inc., Istanbul, Turkey). Informed consents were obtained from all patients. The same senior surgeon operated all of these patients. The Ethics Committee of Ufuk University has permitted this study (date/document number: 04012017/9).

Our TXA protocol consisted of three stages. First, $15 \mathrm{mg} / \mathrm{kg}$ of TXA were given as infusion over 10 minutes before inflation of tourniquet, secondly, two grams of TXA completed up to $100 \mathrm{cc}$ with normal saline to irrigate wound before closure of arthrotomy and, eventually $7.5 \mathrm{mg} / \mathrm{kg}$ of TXA was given as infusion 3 hourly for 24 hours and hemowac drain was removed at $24 \mathrm{~h}$ postoperative after the given last dosage. Patients were operated under general anesthesia or spinal and/or epidural aneshtesia by applying a thigh pneumatic tourniquet inflated to $300 \mathrm{mmHg}$ in supine position. A midline incision and medial parapatellar arthrotomy were used. All patients were undergone unilateral knee cemented knee prosthesis by NexGen LPS-Flex (Zimmer Inc., Warsaw, IN, USA) (posterior cruciate ligament sacrificing design) fixed bearing knees prosthesis with no patellar resurfacing. Immediately after component placement and irrigating by normal saline, two grams of TXA completed up to $100 \mathrm{cc}$ with normal saline was used. After five minutes, the irrigate was suctioned. Routine closure was performed with hemowac drains. Compressive dressings were applied from toe to thigh, like Jones' dressings. Surgical hemowac drain was kept in negative pressure after 30 minutes keeping closed. $4.000 \mathrm{IU}$ of low molecular weight heparin (LMWH) (Clexane, Aventis Inc., Istanbul, Turkey) was given all patients subcutaneously 6 hours postoperatively for the spinal anesthesia group or immediately after surgery for the general anesthesia group.

Physical examination for DVT screening was applied to all patients routinely. Total blood counts were seen on postoperative day 0,1,2 and 3. Preoperative and postoperative day 3 serum hemoglobin levels were compared, and blood loss was assessed according to formula of Nadler and Good. ${ }^{1,21}$ Patients were considered for blood transfusion if they had symptomatic hypotension, palpitations, and shortness of breath, lightheadedness or a postoperative hemoglobin level less than $7 \mathrm{~g} / \mathrm{dl}$. All patients were mobilized after removing the hemowac drains. All patients were discharged from the hospital with anticoagulant treatment on postoperative day 3. Routine 4.000 IU of LMWH was given 10 days for anticoagulant treatment if there were no additional risk factors. Patients were checked on postoperative 3rd. and 6th. week for DVT screening and physical examination.

Statistical analysis of two groups was achieved using the Student's t-test, Mann-Whitney U test, continuity correction (Yates) test, Fisher's exact test, and Pearson correlation coefficient method. The parameters suitability for normal distribution was assessed by Shapiro Wilks test. The confidence level was $95 \%$ and significance was set at $p<0.05$. Analyses were achieved using SPSS v. 15 for Windows (SPSS Inc., Chicago, IL, USA) software.

\section{Results}

In this study, 58 patients who underwent primary TKA, was divided into two groups. First group was composed of 29 patients who administered TXA and second group was composed of 29
Sakarya Med $\mathrm{J}$

$2018 ; 8(2): 423-431$

BASAT et al.

The Importance of Tranexamic Acid

on Total Knee Arthroplasty 
Sakarya Med J.

2018;8(2):423-431

patients who did not. There were no statistical differences in preoperative baseline values between two groups in terms of, age, gender, weight, height, body mass index (BMI), side, serum hemoglobin(hgb) and hematocrit (htc) level, total blood volume, platelet count, INR, and aPTT. Also, no statistical differences were detected between two groups for length of hospitalization, type of anesthetic method utilized, duration of surgery, DVT and PE incidence during postoperative period, 6th. week postoperative follow up active range of motion levels. The demographic characteristic could be seen in Table 1.

\begin{tabular}{|c|c|c|c|c|}
\hline & & Non TXA & TXA & $p$ \\
\hline & & $\operatorname{avg} \pm S d$ & avg $\pm S d$ & \\
\hline \multirow{2}{*}{ Age } & Male & $65.25 \pm 2.5$ & $64.5 \pm 1.73$ & \multirow{2}{*}{0.639} \\
\hline & Female & $67.28 \pm 8.49$ & $67.04 \pm 8.2$ & \\
\hline \multirow{2}{*}{ Gender } & Male & $4(13.8 \%)$ & $4(13.8 \%)$ & \multirow{2}{*}{1.000} \\
\hline & Female & $25(86.2 \%)$ & $25(86.2 \%)$ & \\
\hline \multirow{2}{*}{ Side } & Right & $14(48.3 \%)$ & $12(41.4 \%)$ & \multirow{2}{*}{0.792} \\
\hline & Left & $15(51.7 \%)$ & $17(58.6 \%)$ & \\
\hline \multirow{2}{*}{ Weight (kg) } & Male & $107 \pm 11.97$ & $108 \pm 21.35$ & 0.938 \\
\hline & Female & $80.52 \pm 12.85$ & $79.04 \pm 11.51$ & 0.670 \\
\hline \multirow{2}{*}{ Height (cm) } & Male & $1.63 \pm 0.04$ & $1.61 \pm 0.03$ & 0.048 \\
\hline & Female & $1.63 \pm 0.04$ & $1.61 \pm 0.03$ & 0.048 \\
\hline \multirow{2}{*}{ BMI (kg/m2) } & Male & $36.65 \pm 5.11$ & $36.58 \pm 6.46$ & 0.986 \\
\hline & Female & $30.41 \pm 4.43$ & $30.64 \pm 4.45$ & 0.857 \\
\hline \multirow[b]{2}{*}{ Anesthesia } & Spinal & $21(72.4 \%)$ & $21(72.4 \%)$ & \multirow[b]{2}{*}{1.000} \\
\hline & $\begin{array}{l}\text { General } \\
\text { endotracheal }\end{array}$ & $8(27.6 \%)$ & $8(27.6 \%)$ & \\
\hline DoS(minutes) & & $90.93 \pm 8.4$ & $90.59 \pm 8.73$ & 0.879 \\
\hline LoH (days) & & $4.52 \pm 0.51$ & $4.41 \pm 0.5$ & 0.434 \\
\hline Blood volume (L) & & $4.59 \pm 0.72$ & $4.51 \pm 0.71$ & 0.791 \\
\hline \multirow{2}{*}{ Preop hgb (g/dL) } & Male & $14.5 \pm 0.79$ & $14.95 \pm 0.73$ & 0.435 \\
\hline & Female & $13.04 \pm 0.65$ & $13.06 \pm 1.02$ & 0.961 \\
\hline \multirow{2}{*}{ Preop htc (\%) } & Male & $43.8 \pm 3.93$ & $44.65 \pm 3.66$ & 0.762 \\
\hline & Female & $38.17 \pm 2.46$ & $38.56 \pm 3.41$ & 0.650 \\
\hline $\begin{array}{l}\text { Platelet count } \\
\text { preoperatively }\end{array}$ & & $269.76 \pm 58.21$ & $259.98 \pm 41.68$ & 0.465 \\
\hline INR & & $1.01 \pm 0.12$ & $1 \pm 0.11$ & 0.806 \\
\hline aPTT & & $28.79 \pm 2.02$ & $27.86 \pm 2.13$ & 0.094 \\
\hline \multirow{3}{*}{ ASA status } & I & $9(31 \%)$ & $8(27.6 \%)$ & \multirow{3}{*}{0.958} \\
\hline & II & $18(62.1 \%)$ & $19(65.5 \%)$ & \\
\hline & III & $2(6.9 \%)$ & $2(6.9 \%)$ & \\
\hline 6 week ROM $\left(^{\circ}\right)$ & & $100.93 \pm 5.71$ & $100.66 \pm 5.35$ & 0.850 \\
\hline \multirow{3}{*}{ IV TXA dosage (mg) } & Preop & 0 & $1000.34 \pm 115.01$ & \\
\hline & Postop & 0 & $2491.03 \pm 489.05$ & \\
\hline & Total & 0 & $3736.55 \pm 733.58$ & \\
\hline
\end{tabular}




\begin{tabular}{|c|c|c|c|c|}
\hline \multirow{9}{*}{$\begin{array}{l}\text { Preoperative } \\
\text { Comorbidities }\end{array}$} & Stroke or TIA & 0 & 0 & \multirow{9}{*}{0.642} \\
\hline & $\begin{array}{l}\text { Deep Vein } \\
\text { Thrombosis }\end{array}$ & 0 & 0 & \\
\hline & $\begin{array}{l}\text { Pulmonary } \\
\text { Embolism }\end{array}$ & 0 & 0 & \\
\hline & $\begin{array}{l}\text { Myocardial } \\
\text { Infarction }\end{array}$ & 0 & 0 & \\
\hline & $\begin{array}{l}\text { Systolic Heart } \\
\text { Failure }\end{array}$ & 0 & 0 & \\
\hline & Renal Impairment & 0 & 0 & \\
\hline & Diabetes mellitus & 11 & 9 & \\
\hline & COPD or Asthma & 0 & 0 & \\
\hline & $\begin{array}{l}\text { Coagulopathy or } \\
\text { Bleeding Disorder }\end{array}$ & 0 & 0 & \\
\hline
\end{tabular}

Postoperative hgb and htc levels were detected to be significantly lower in the non-TXA group (average, $10.38 \mathrm{~g} / \mathrm{dl}, 31.6 \%$,) respectively as compared to the TXA group (average $11.66 \mathrm{~g} / \mathrm{dl}$, $34.54 \%)$ respectively $(p=0.001)$. Estimated blood loss, hidden blood loss, and drain output were detected to be significantly higher in the non-TXA group (average, $3291.62 \mathrm{ml}, 2510.76 \mathrm{ml}$, $780.86 \mathrm{ml}$ respectively) as compared to the TXA group (average, $698 \mathrm{ml}, 484.66 \mathrm{ml}, 213.79 \mathrm{ml}$ respectively) $(\mathrm{p}=0.001)$. Transfusion rate was significantly lower in TXA group (average, 0.03 ) as compared to the non-TXA group (average, 0.66$)(p=0.001)$. The blood bank costs were found to be significantly higher (average, $37.2 \$$ ) in the non-TXA group as compared to the TXA (average, $1.6 \$$ ). And average pharmacy cost of TXA was 5.7 \$ in the TXA group. The total direct cost, which included sum of given transfusion units and TXA, was also significantly higher in the non-TXA group (average, $37.2 \$$ ) as compared to the TXA group (average, $7.3 \$$ ) ( $p=0.001)$. This was average 29.9 savings per case in the TXA group. Patients' statistical findings could be seen in Table 2. We have not seen any deep vein thrombosis or any pulmonary embolous cases in any group as complication. We have not detected any surgical wound complications or infections and any hypersensitivity reactions or adverse effects of TXA.

\begin{tabular}{|l|c|c|c|}
\hline \multicolumn{4}{|l|}{ Table 2. Patients' statistical findings } \\
\hline & Non TXA & TXA & p \\
\hline Pharmacy cost (\$) & avg \pm Sd & avg \pm Sd & \\
\hline Blood bank cost (\$) & 0 & $5.7 \pm 1.1$ & 0.001 \\
\hline Total cost & $37.2 \pm 27.1$ & $1.6 \pm 10.7$ & 0.001 \\
\hline Postop hgb (g/dL) & $37.2 \pm 27.1 \$$ & $7.3 \pm 11.9$ & 0.001 \\
\hline Postop htc (\%) & $10.38 \pm 0.41$ & $11.66 \pm 0.9$ & 0.001 \\
\hline Estimated blood loss (ml) & $31.6 \pm 1.51$ & $34.54 \pm 2.81$ & 0.001 \\
\hline Hidden blood loss (ml) & $3291.62 \pm 1498.9$ & $698 \pm 786.48$ & 0.001 \\
\hline Drainage (ml) & $2510.76 \pm 1347.71$ & $484.66 \pm 732.44$ & 0.001 \\
\hline Patients transfused & $780.86 \pm 190.63$ & $213.79 \pm 96.04$ & 0.001 \\
\hline Mean units transfused & $19(65.5 \%)$ & $1(3 \%)$ & \\
\hline $\begin{array}{l}\text { Prep: preoperative. postop: postoperative. } \\
\text { Significant } p \text { values are written in bold. }\end{array}$ & $0.66 \pm 0.48$ & $0.03 \pm 0.19$ & 0.001 \\
\hline
\end{tabular}


Sakarya Med J.

$2018 ; 8(2): 423-431$

\section{Discussion}

Blood loss reducing management of unilateral primary TKA has been a popular issue recently. 1, 2, 5, 6, 9-11,13, 22 Allogenic blood transfusion has been used commonly for postoperative anemia following TKA. In many institutions, the erythrocyte suspensions are routinely arranged preoperatively for TKA. ${ }^{9,22,23}$ But this method has numerous well-known side effects and is considered not being a cost effective method for replacement of blood loss after surgery. ${ }^{6,23-25}$ Numerous medical managements also have been used for reducing blood loss. ${ }^{8-10,13,26,27}$ TXA has been used as one of the medical treatments for reducing blood loss because It can be found easily, it is cheap, potent drug and safer in use for reducing blood loss. 1, 8, 10, 13, 24, 25

There are numerous published literatures on TXA's role, dose and administration way. But there is no consensus on what dose and administration way are effective for reducing blood loss after TKA. 6, 10-12 In our study, TXA was administered both in a topical and systemic way. In the literature, bolus dosage for TXA ranged between 15-30 mg/kg and was given before inflation or deflation of the tourniquet. ${ }^{10-13}$ We applied bolus from $15 \mathrm{mg} / \mathrm{kg}$ TXA 10 minutes before inflation of the tourniquet. In the literature, topical dosage was ranged between $0.25-3 \mathrm{~g}$ of TXA within normal saline to irrigate wound before the closure of arthrotomy or after wound closure. It was given through to the drain and drain was clamped varying minutes..$^{5,6,10,12,13}$ We prepared two grams of TXA completed up to $100 \mathrm{cc}$ with normal saline to irrigate wound before the closure of arthrotomy. Eventually, $7.5 \mathrm{mg} /$ $\mathrm{kg}$ of TXA was given as infusion per 3 hours period for the first 24 hours. Because blood levels of TXA are reduced by half from 2 to $3 \mathrm{~h}$ after intravenous administration. ${ }^{28}$ Zhao-Yu6 et al reported their results of meta-analysis about intra-articular TXA injection during total knee arthroplasty. They analyzed 647 patients from 6 studies and reported that intraarticular injection of TXA in patients undergoing TKA may reduce total blood loss and the need for blood transfusions. Gandhi11 et al reported that their metaanalysis results about TXA in both total knee and hip arthroplasty. In that study, various dosages of TXA were used and they reduced the amount of total blood loss, however in those metaanalysis, the amount of hidden blood loss was not mentioned. Good1 et al were analyzed 51 patients' outcomes. ${ }^{24}$ patients TXA was applied intravenously and 27 patients were not. According to that study, TXA decreased total blood loss by nearly $30 \%$, drainage volume by nearly $50 \%$, thus reducing transfusion needs. But hidden blood loss was not affected as same as drainage volume by TXA. Consequently, hidden blood loss can be as much as drainage volume. Therefore, they stated that it must be highly questionable to use the "volume of drainage fluid" as a measure of blood loss in primary TKA. ${ }^{1}$ In our study, we detected that hidden blood loss was more than drainage volume in both groups, however hidden blood loss in the TXA group is much less than non-TXA groups and the difference is significant. It showed us that; preoperative intravenous application, topical irrigation and 3 hourly postoperative intravenous regimen of TXA up to 24 hours were enough to reduce both the blood loss and hidden loss. But the most important finding for our study was that the proportion of reduction in hidden blood loss was affected than proportion of reduction in drainage volume. In the literature, rates of postoperative hematoma formation with minor or major were reported between $0 \%$ to $10 \%$ of patients and many of them are healed spontaneously with conservative treatment and some of them required surgical intervention because of infection. ${ }^{17-20}$ Negative effect of hidden blood loss could be seen in the study of Galat ${ }^{18}$ et al in which they evaluated 17.784 primary total knee arthroplasties during the 23 years. They reported that patients requiring surgical intervention within thirty days from the index primary total knee arthroplasty because of postoperative hematoma having a $10.5 \%$ risk for deep 
infection and $12.3 \%$ risk for major re-operation up to two years. Parviziz ${ }^{20}$ et al reported the their results in which septic failure following primary or revision total hip or total knee arthroplasty had a risk of hematoma configuration 12.6 times more than their control group. That way, they revealed a relationship between excessive anticoagulation causing hematoma in the surgical site and the development of periprosthetic infection. Although we didn't see any infection in both groups, we agree with relationship between hematoma and periprosthetic infection and we also think that we make contribution for reduction of periprosthetic infection due to hematoma following the total knee arthroplasty via reducing hidden blood loss with our combined method.

Besides, reducing blood transfusion rates, cost benefit analysis should be checked for determining true incomes of using TXA. Decreasing blood transfusion rates because of using of TXA provides significant reduction in average cost on per patient in the TKA. The average pharmacy-drug cost was higher in TXA group than non-TXA group, zero, 5.7 \$ respectively. However total cost should be calculated by summing up pharmacy costs, blood costs, and hospitalization costs all together. In our study, the length of stay was nearly same, but total blood usage was higher in non-TXA group. When average total cost was calculated, non-TXA cost was significantly higher than TXA group, 37.2 and 7.3 \$ respectively. We detected about 30 \$ saving in per patient. Sepah25 et al showed 99 patients' results administered intravenous TXA. According to that study, TXA is a cost-effective method for due to decreasing blood transfusion rates. Ralley ${ }^{24}$ et al reported similar results and concluded that reduction was approximately 65.00 Canadian dollars each patient fee of transfusion using TXA. Good1 et al also concluded that intravenous administration of TXA was cost effective in TKA. Their immediate saving per patient given TXA was about $40 £$. Alshryda ${ }^{10}$ et al reported metaanalysis results about TXA in primary total knee arthroplasty. Length of stay was not influenced by intravenous TXA administration in TKA. Our results are similar; however, we detected minimal differences between TXA and non-TXA groups. But this difference was not significant.

The thromboembolic events depend on using TXA remains controversial. ${ }^{10,11,13,26,27,29}$ TXA initiates its effects on injured tissue. TXA does not influence fibrinolytic activity in vein walls. These findings can be explained why thromboembolic events have been seen rarely when TXA was used for reducing blood transfusion rates in TKA. ${ }^{26,29}$ Gillette ${ }^{30}$ et al used intravenous TXA for antifibrinolytic drugs in both hip and knee arthroplasty to decrease blood loss intraoperatively and gave three different postoperative prophylactic regimens, aspirin alone, warfarin and dalteparin Na. They detected that TXA did not increase the thromboembolic complications such as deep vein thrombosis, pulmonary embolus, myocardial infarction, and cerebrovascular accident. Alshryda ${ }^{10}$ et al published their meta-analysis about usage of TXA in TKA. In that study, there were not significant differences about PE, DVT between TXA groups and non-TXA groups. And they concluded that; TXA usage had not direct relationship with PE and DVT complications. These similar results can be seen in other studies in the literature. ${ }^{1,10,12,13,25,26,28-30}$ In our study we detected no thromboembolic complications clinically however, we did not make routine investigations with Doppler ultrasound to rule out DVT. Studies show that DVT occurs frequently within postoperative 30 days and rarely can be detected within postoperative two days' time. ${ }^{26,30}$ The routine Doppler ultrasound investigation for a patient staying at hospital after primary TKA is not fundamental for detection of DVT. Instead, investigation of suspected venous thromboembolic events when clinical signs arose is advisable.
Sakarya Med J.

2018;8(2):423-431

BASAT et al.

The Importanee of Tranexamic Acid

on Total Knee Arthroplasty 
The small sample size is the limitation of this study. Although combined TXA method was effective for total blood loss and hidden blood loss we don't know whether only topical method or systemic method are effective or enough for reduction for hidden blood loss or total blood loss. We think that four groups composed of only topical group, only systemic group, both systemic and topical group and control group are suitable to reveal of TXA effects on total blood loss and hidden blood loss, however we had not so much patients and an institutional review board approval to compare groups used like these protocols. Direct correlation between amount of hidden blood loss and periprosthetic infection rate may be objectively evaluated in larger patient groups that be given and not given such a combined TXA protocols. Thus, it may reveal whether TXA administration indirectly reduces periprosthetic infection rate by decreasing hidden blood loss. Lack of number of patient is an important limitation for our study in order to evaluate that potential effect of TXA protocol.

\section{Conclusion}

We have detected that combined topical and continuous up to 24 hours intravenous administration of TXA reduced the total blood loss and decreased drainage volume, as well as reducing the hidden blood loss. Thus, postoperative transfusion necessity reduced, and allogenic transfusion complications may be prevented. Also, periprosthetic infection rate could be reduced this combined method by reduced hidden blood loss. This combined method is cost-effective and easier, but the most important side is that it doesn't increase thromboembolic complications. 
1. Good L, Peterson E and Lisander B. Tranexamic acid decreases external blood loss but not hidden blood loss in total knee replacement. $\mathrm{Br}$ ) Anaesth 2003; 90: 596-599. 2003/04/17.

2. Lotke PA, Faralli V], Orenstein EM, et al. Blood loss after total knee replacement. Effects of tourniquet release and continuous passive motion. J Bone Joint Surg Am 1991; 73: 1037-1040. 1991/08/01.

3. Sehat KR, Evans R and Newman JH. How much blood is really lost in total knee arthroplasty?. Correct blood loss management should take hidden loss into account. Knee 2000; 7: 151-155. 2000/08/06.

4. Lee SH, Cho KY, Khurana S, et al. Less blood loss under concomitant administration of tranexamic acid and indirect factor $X a$ inhibitor following total knee arthroplasty: a prospective randomized controlled trial. Knee Surg Sports Traumatol Arthrosc 2013; 21: 2611-2617. 2012/10/12. DOI: 10.1007/s00167-012-2213-1.

5. Georgiadis AG, Muh SJ, Silverton CD, et al. A prospective double-blind placebo controlled trial of topical tranexamic acid in total knee arthroplasty. J Arthroplasty 2013; 28: 78-82. 2013/08/03. DOI: 10.1016/j. arth.2013.03.038

6. Zhao-Yu C, Yan G, Wei C, et al. Reduced blood loss after intra-articular tranexamic acid injection during total knee arthroplasty: a meta-analysis of the literature. Knee Surg Sports Traumatol Arthrosc 2014; 22: 31813190. 2013/12/20. DOI: 10.1007/s00167-013-2814-3.

7. Imai N, Dohmae Y, Suda K, et al. Tranexamic acid for reduction of blood loss during total hip arthroplasty. J Arthroplasty 2012; 27: 1838-1843. 2012/06/19. DOI: 10.1016/j.arth.2012.04.024.

8. Astedt B. Clinical pharmacology of tranexamic acid. Scand J Gastroenterol Suppl 1987; 137: 22-25. 1987/01/01.

9. Schulman S. Pharmacologic tools to reduce bleeding in surgery. Hematology Am Soc Hematol Educ Program 2012; 2012: 517-521. 2012/12/13. DOI: 10.1182/asheducation-2012.1.517.

10. Alshryda S, Sarda P, Sukeik M, et al. Tranexamic acid in total knee replacement: a systematic review and meta-analysis. J Bone Joint Surg Br 2011; 93: 1577-1585. 2011/12/14. DOI: 10.1302/0301-620X.93B12.26989.

11. Gandhi R, Evans HM, Mahomed SR, et al. Tranexamic acid and the reduction of blood loss in total knee and hip arthroplasty: a meta-analysis. BMC Res Notes 2013; 6: 184. 2013/05/09. DOI: 10.1186/1756-0500 6-184.

12. Huang $F$, Wu $D$, Ma $G$, et al. The use of tranexamic acid to reduce blood loss and transfusion in major orthopedic surgery: a meta-analysis. J Surg Res 2014; 186: 318-327. 2013/10/01. DOI: 10.1016/j. jss.2013.08.020.

13. Yang ZG, Chen WP and Wu LD. Effectiveness and safety of tranexamic acid in reducing blood loss in total knee arthroplasty: a meta-analysis. J Bone Joint Surg Am 2012; 94 : 1153-1159. 2012/05/25. DOI: 10.2106/ JBJS.K.00873.

14. Gaulrapp $\mathrm{H}$ and Eckstein $\mathrm{S}$. [Value of ultrasound after endoprosthesis implantation of the knee joint]. Z Orthop Ihre Grenzgeb 2001; 139 : 127 133. 2001/06/02. DOI: $10.1055 / \mathrm{s}-2001-15043$

15. Harrap RS, Whyte GS, Farrugia A, et al. Some characteristics of blood shed into the Solcotrans postoperative orthopaedic drainage/reinfusion system. Med J Aust 1992; 157: 95-96. 1992/07/20.

16. Sehat KR, Evans RL and Newman JH. Hidden blood loss following hip and knee arthroplasty. Correct management of blood loss should take hidden loss into account. J Bone Joint Surg Br 2004; 86: 561-565. 2004/06/04.
17. Adelani MA, Johnson SR, Keeney JA, et al. Clinical outcomes following re-admission for non-infectious wound complications after primary total knee replacement. Bone Joint J 2014; 96-B: 619-621. 2014/05/03. DOI: 10.1302/0301-620X.96B5.33479.

18. Galat DD, McGovern SC, Hanssen AD, et al. Early return to surgery for evacuation of a postoperative hematoma after primary total knee arthroplasty. J Bone Joint Surg Am 2008; 90: 2331-2336. 2008/11/04. DOI: 10.2106/JBJS.G.01370

19. Jamsen E, Huhtala H, Puolakka T, et al. Risk factors for infection after knee arthroplasty. A register-based analysis of 43,149 cases. J Bone Join Surg Am 2009: 91: 38-47. 2009/01/06. DOI: 10.2106/JBJS.G.01686.

20. Parvizi J, Ghanem E, Joshi A, et al. Does "excessive" anticoagulation predispose to periprosthetic infection? J Arthroplasty 2007; 22: 24-28 2007/10/11. DOI: 10.1016/j.arth.2007.03.007.

21. Nadler SB, Hidalgo JH and Bloch T. Prediction of blood volume in normal human adults. Surgery 1962; 51: 224-232. 1962/02/01.

22. Morais S, Ortega-Andreu M, Rodriguez-Merchan EC, et al. Blood transfusion after primary total knee arthroplasty can be significantly minimised through a multimodal blood-loss prevention approach. Int Orthop 2014; 38: 347-354. 2013/12/10. DOI: 10.1007/s00264-013-2188-7.

23. Madjdpour C and Spahn DR. Allogeneic red blood cell transfusions: efficacy, risks, alternatives and indications. $\mathrm{Br}$ ) Anaesth 2005; 95: 33-42. 2004/10/16. DOI: 10.1093/bja/aeh290.

24. Ralley FE, Berta D, Binns V, et al. One intraoperative dose of tranexamic Acid for patients having primary hip or knee arthroplasty. Clin Orthop Relat Res 2010; 468: 1905-1911. 2010/01/12. DOI: 10.1007/s11999009-1217-8.

25. Sepah Y], Umer M, Ahmad T, et al. Use of tranexamic acid is a cost effective method in preventing blood loss during and after total knee replace ment. J Orthop Surg Res 2011; 6: 22. 2011/05/24. DOI: 10.1186/1749 799X-6-22.

26. Ross ) and Al-Shahi Salman R. The frequency of thrombotic events among adults given antifibrinolytic drugs for spontaneous bleeding: systematic review and meta-analysis of observational studies and randomized trials. Curr Drug Saf 2012; 7: 44-54. 2012/06/06.

27. Struijk-Mulder MC, Horstmann WG, Verheyen CC, et al. Ten-year followup on Dutch orthopaedic blood management (DATA III survey). Arch Orthop Trauma Surg 2014; 134: 15-20. 2013/11/28. DOI: 10.1007/ s00402-013-1893-4.

28. Iwai T, Tsuji S, Tomita T, et al. Repeat-dose intravenous tranexamic acid further decreases blood loss in total knee arthroplasty. Int Orthop 2013 37: 441-445. 2013/02/02. DOI. 10.1007/s00264-013-1787-7.

29. Astedt B, Liedholm $P$ and Wingerup L. The effect of tranexamic acid on the fibrinolytic activity of vein walls. Ann Chir Gynaecol 1978; 67: 203 205. 1978/01/01.

30. Gillette BP, DeSimone LI, Trousdale RT, et al. Low risk of thromboembolic complications with tranexamic acid after primary total hip and knee arthroplasty. Clin Orthop Relat Res 2013; 471: 150-154. 2012/07/21. DOI: 10.1007/s11999-012-2488-z. 